\title{
E-BUSINESS IMPACTS AND OBSTACLES FROM THE PERSPECTIVE OF EUROSTAT AND STUDENTS
}

\author{
Viktorija Sulčič, University of Primorska Faculty of Management, Slovenia, viktorija.sulcic@fm-kp.si \\ Dušan Lesjak, University of Primorska, Faculty of Management, Slovenia, dusan.lesjak@fm-kp.si
}

\begin{abstract}
In the paper, firstly, the comparison of e-business among SMEs in Slovenian and some other EU countries and regions is presented. Even if the broadband access to the Internet in Slovenia is not a problem anymore, $B 2 B$ e-business is not that common among Slovenian SMEs as it is in the EU countries. Secondly, the e-business impacts and obstacles among Slovenian SMEs are discussed from two perspectives - from the point of view of SMEs and students. Among Slovenian SMEs implementing e-business was done mostly due to management demand and has an impact on communication inside and outside enterprises. The e-business implementing or maintaining cost and the lack of staff could be a serious obstacle for $e$ business implementation and usage.
\end{abstract}

Keywords: e-business, SMEs, Slovenia

\section{INTRODUCTION}

SMEs are socially and economically important, since they represent $99 \%$ of all enterprises in the EU and provide around 65 million jobs and contribute to entrepreneurship and innovation to a great extend (3). Therefore ICT usage among SMEs is economically important too.

Nowadays e-business is not primary about ICT, but about accessing, providing and sharing information in business networks i.e.. it is about doing business in the advanced digital economy (16). Although today firms continue to use ICT cost cutting, ICT is increasingly recognised as an important tool for innovation and increasing revenues. New services and new ways of working within value networks have appeared. Firms compete in new ways and they are forced to cooperate. The knowledgeintensive activities became more and more important. Firms are increasingly focusing on their core competencies and they outsource non-core business processes.

EC forecasts a number of changes in using ICT for doing business: (5)

- ICT infrastructure becomes mature, particular among SMEs;

- E-business goes far beyond concluding transaction - ICT is used to do better services for customers and to create sustained relationships with them;

- ICT improves the transparency of internal processes, which facilitates planning and decision-making;

- Outsourcing non-core business processes;

- ICT usage for sustainable industrial development, where ICT is used to reduce energy usage;

- ICT enables the introduction of innovation in business processes.

ICT offers opportunities and challenges to small firms. On the one hand, small firms have the opportunity to expand their markets, to cooperate with others and to support their processes by ICT, because appropriate solutions for SMEs have been developed, and on the other hand, SMEs often lack ICT investment strategies and the ability to comply with different systems in parallel especially when SMEs are trading with larger firms (5).

In recent years, various studies confirmed that Slovenia is slightly above the EU-25 average regarding ICT characteristics, e.g. Stare et al. (10), IDC (8), and Eurostat (7). In addition, Vehovar and Jovan (18) compared Slovenian companies with SIBIS (Statistical Indicators Benchmarking the Information Society, a project in the Information Society Programme founded by the EC) research among EU-15 countries and they found that Slovenia was above the EU-15 average in basic ICT (computers, internet access, web pages); however it lagged behind the EU-15 average in some advanced technologies (video-conferencing, intranet, etc.) (10). Similar findings arose from the Eurostat (6) study on ICT among companies.

In the paper, firstly, a comparison between SMEs in Slovenia and the EU in terms of ICT usage for ebusiness purposes is presented with the aim to find out the similarities and differences or gaps and the potential reasons for that. Secondly, findings from the research regarding e-business impacts and obstacles among Slovenian SMEs and e-business course students are introduced and discussed.

\section{SMEs AND ICT IN SLOVENIA AND ABROAD}

In 2006, in Slovenia $96.2 \%$ of enterprises are micro or small in which $45 \%$ of all employees are 
employed and in less than $1 \%$ of large companies one third of employees are employed (Error! In the EU, $99 \%$ of all enterprises are SMEs in which there are $67.1 \%$ employees (4). The main reasons why the percentage of employees in SMEs in Slovenia is more than 20 percentage points lower than the EU average, is firstly, due to the final stage of the transition process from former

\section{Reference source not found.).}

socio-economical system where there were predominately large state owned companies and secondly, the smallness of the economy, which is together reflected in the relative large percent of employees in micro firms.

Table 1. Slovenian enterprises (in 2006)

\begin{tabular}{lcrrrr}
\hline \multicolumn{1}{c}{ Enterprise category } & Employees & \# Enterprises & \multicolumn{1}{c}{ \% } & \# Employees & \% \\
\hline Micro & $<10$ & 33.371 & 82.4 & 171.535 & 27.6 \\
Small & $<50$ & 5.601 & 13.8 & 108.554 & 17.4 \\
Medium-sized & $<250$ & 1.255 & 3.1 & 131.223 & 21.1 \\
Large & $250+$ & 284 & 0.7 & 211.057 & 33.9 \\
\hline & & 40.511 & 100.0 & 622.369 & 100.0 \\
\hline
\end{tabular}

EU-15 countries are more economically developed than EU-25 (Slovenia with other predominantly Eastern European countries joined EU in 2004) or EU-27 countries (Romania and Bulgaria joined in 2007) (Table 2).

Table 2. GDP at market prices and IT/communication expenditure

\begin{tabular}{|c|c|c|c|}
\hline \multirow[t]{2}{*}{$\begin{array}{c}\text { Region / } \\
\text { State }\end{array}$} & \multirow{2}{*}{$\begin{array}{l}\text { GDP per } \\
\text { capita (in } \\
2007)\end{array}$} & \multicolumn{2}{|c|}{$\begin{array}{c}\% \text { of GDP } \\
\text { expenditure for ... (in } \\
2006)\end{array}$} \\
\hline & & IT & Communication \\
\hline EU-15 & $29,100 €$ & 2.7 & 2.9 \\
\hline EU-25 & $26,000 €$ & NA & NA \\
\hline EU-27 & $24,700 €$ & 2.7 & 3.0 \\
\hline Slovenia & $16,600 €$ & 2.2 & 3.6 \\
\hline USA & $33,400 €$ & 3.3 & 2.1 \\
\hline
\end{tabular}

Source: Eurostat (6). Legend: NA - data not available

Table 3, the comparison between Slovenia, USA, Japan, the East Asia and Pacific group is presented. Slovenian GDP increased faster than in the USA and Japan, which is logical due to the transition
The negative gap between Slovenia and EU-27 countries is smaller when a comparison is made

with GDP per capita in Purchasing Power Standards that placed Slovenia with 88.0 index behind the EU-27 countries (100.0) in 2006, but in 2008 this gap was reduced by more than 3 percentage points to 91.1 .

Slovenia spends lower \% of GDP for IT compared to the EU average, which in a way reflects the smallness of its economy, yet on the other hand spends a larger \% of GDP for communications, which results in the availability of various modern communication services.

In

process Slovenia has been going through. It is known as well as from the investments in telecommunications that Slovenians use mobile phones more frequently $(90.7 \%)$ than citizens in more developed country.

Table 3. ICT usage around the world

\begin{tabular}{lrrrr}
\hline \multicolumn{1}{c}{ Variables } & Slovenia & USA & Japan & $\begin{array}{r}\text { East Asia } \\
\text { \& Pacific }\end{array}$ \\
\hline Population (in millions) & 2 & 299 & 128 & 1,899 \\
GDP growth (1995-2000\&2000-2006 in \%) & 3.7 & 2.6 & 1.5 & 8.6 \\
Mobile phone subscribers (in \%) & 90.7 & 77.8 & 79.6 & 34.7 \\
Internet users (in \%) & 62.3 & 69.5 & 68.5 & 11.1 \\
Personal computers (in \%) & 40.4 & 76.2 & 67.6 & 4.1 \\
Broadband subscribers (in \%) & 13.4 & 19.42 & 20.16 & 3.56 \\
ICT expenditure (\% of GDP) & 3.1 & 8.7 & 7.9 & 5.3 \\
E-government readiness index (from 0 to 1) & 0.67 & 0.86 & 0.77 & 0.43 \\
\hline Source: WorldBank (19)
\end{tabular}

Source: WorldBank (19)

According to the WorldBank (19) Slovenian citizens demonstrate greater readiness for egovernment than countries from East Asia and
Pacific region (0.67 vs 0.43 ) but less than it was ascertained in the USA and Japan. 


\section{E-BUSINESS AMONG SMES}

Development of the web-based e-commerce solutions offer to SMEs more opportunities in marketing, business expansion, business launches, cost cutting and tighter partner alliances (17). In Table 4, data about firms, where at least $1 \%$ of their purchasing and selling in 2007 was done online are presented. Purchasing (P) and selling (S) was performed through the Internet or/and other electronic networks.

Table 4. Enterprise online purchasing and selling (in 2007)

\begin{tabular}{|c|c|c|c|c|c|c|c|}
\hline \multirow[t]{2}{*}{ Enterprise } & $\begin{array}{c}\text { EU-27 } \\
(\%)\end{array}$ & \multicolumn{2}{|c|}{$\begin{array}{c}\text { EU-25 } \\
(\%)\end{array}$} & \multicolumn{2}{|c|}{$\begin{array}{c}\text { EU-15 } \\
(\%)\end{array}$} & \multicolumn{2}{|c|}{$\begin{array}{c}\text { Slovenia } \\
(\%)\end{array}$} \\
\hline & $\begin{array}{ll}\mathbf{P} & \mathbf{S}\end{array}$ & $\mathbf{P}$ & $\mathbf{S}$ & $\mathbf{P}$ & & $\mathbf{P}$ & $\mathbf{S}$ \\
\hline & 28 & 29 & 15 & 33 & 10 & 20 & 8 \\
\hline
\end{tabular}

Medium-

\begin{tabular}{lllllllll}
$\begin{array}{l}\text { Medium- } \\
\text { sized }\end{array}$ & 34 & 20 & 36 & 22 & 41 & 24 & 22 & 14 \\
Large & 44 & 31 & 46 & 33 & 53 & 37 & 29 & 31 \\
\hline
\end{tabular}

Source: Eurostat (6)

Despite the Internet broadband connection expandability (Table 4) there is a gap between ebuying or e-purchasing (P) and e-selling (S) activities among Slovenian enterprises and enterprises in other EU countries. The gap is bigger between Slovenian and EU large enterprises in ebuying activities for which the reason lies in the fact that Slovenian large companies are, to some extent, providing parts for big EU companies.

Slovenian SMEs are using web pages for various ebusiness purposes. Where data for 2008 are available the comparison between 2007 and 2008 is presented.

Table 5. Slovenian SMEs web pages (in \%)

\begin{tabular}{lcccccc}
\hline Enterprise & $\begin{array}{c}\text { Presence } \\
\mathbf{( 2 0 0 8 )}\end{array}$ & $\begin{array}{c}\text { Index } \\
\mathbf{2 0 0 8 / 2 0 0 7}\end{array}$ & $\begin{array}{c}\text { Products/services } \\
\mathbf{( 2 0 0 7 )}\end{array}$ & $\begin{array}{c}\text { Price lists } \\
\mathbf{( 2 0 0 8 )}\end{array}$ & $\begin{array}{c}\text { Index } \\
\mathbf{2 0 0 8 / 2 0 0 7}\end{array}$ & $\begin{array}{c}\text { Post-selling activities } \\
\mathbf{( 2 0 0 7 )}\end{array}$ \\
\hline Micro & 47.4 & 118.2 & 35.9 & 26.3 & 147.3 & 11.7 \\
Small & 66.6 & 109.1 & 53.5 & 39.6 & 147.6 & 18.1 \\
Medium-sized & 83.6 & 99.6 & 75.4 & 44.9 & 97.3 & 22.4 \\
Large & 96.9 & 102.0 & 91.7 & 72.4 & 129.6 & 31.3 \\
\hline
\end{tabular}

Source: SURS (14), (15)

Logically, the larger the enterprise, the more active it is on the Internet

Table 5 all internet activities have increased from 2007 to 2008 with the exception in the group of medium-sized enterprises. Available data cannot help us to reasonably interpret the reasons for the stagnation of medium-sized enterprise e-business. Table 6.

Table 6. ICT support of business activities (2008)
). This is not that obvious in on-line post-selling activities which are still conducted traditionally. As we can see from the comparison presented in

Internet may be used for various purposes - finance and banking, marketing research or for training and learning as we can see in

\begin{tabular}{lcccccc}
\hline Enterprise & $\begin{array}{c}\text { Banking and } \\
\text { financing }\end{array}$ & $\begin{array}{c}\text { Index } \\
\mathbf{2 0 0 8 / 2 0 0 7}\end{array}$ & $\begin{array}{c}\text { Market data } \\
\text { gathering }\end{array}$ & $\begin{array}{c}\text { Index } \\
\mathbf{2 0 0 8 / 2 0 0 7}\end{array}$ & $\begin{array}{c}\text { - Training and } \\
\text { learning }\end{array}$ & $\begin{array}{c}\text { Index } \\
\mathbf{2 0 0 8} / \mathbf{2 0 0 7}\end{array}$ \\
\hline Micro & 85.0 & 104.0 & 58.5 & 104.9 & 28.8 & 81.7 \\
Small & 91.2 & 100.0 & 67.0 & 94.0 & 38.9 & 86.9 \\
Medium-sized & 93.5 & 96.8 & 79.7 & 99.5 & 66.5 & 104.4 \\
\hline
\end{tabular}

Source: SURS (14), (15)

Among three observed groups, Internet usage changes differently from 2007 to 2008. Micro enterprises increase banking and financing activity on the Internet by $4 \%$. They also use Internet more intensively to gather market data $(+4.9 \%)$. But they use Internet less frequently (81.7) for learning and training purposes. Internet is used less often for learning and training among small enterprises (86.9) as well. It is interesting that medium-sized enterprises are less active in banking and financing (96.8) and they use the Internet less often to collect market data (79.7), but they use the Internet more intensively for training and learning purposes (104.4).

In 2007, ERP were used in $8.1 \%$ of micro and in one fifth of small firms, but in 2008 the ERP usage decreased by a half. Both systems - CRM and ERP were used in 2008 less often among all three observed groups, which is probably related to the economic recession and global financial crisis.

Table 7. Costumer relationship management $(\mathrm{CRM})$ and enterprise resource planning (ERP) (2008) 


\begin{tabular}{lcccc}
\hline Enterprise & CRM & $\begin{array}{c}\text { Index } \\
\text { 2008/2007 }\end{array}$ & ERP & $\begin{array}{c}\text { Index } \\
\text { 2008/2007 }\end{array}$ \\
\hline Micro & 4.9 & 40.9 & 3.3 & 41.1 \\
Small & 11.3 & 58.8 & 12.2 & 59.2 \\
$\begin{array}{l}\text { Medium- } \\
\text { sized }\end{array}$ & 19.8 & 56.2 & 34.3 & 71.3 \\
\hline
\end{tabular}

Source: SURS (14), (15)

\section{E-BUSINESS IMPACTS AND OBSTACLES}

The results presented here are derived from two different research activities performed among two different samples: first research was carried out among Slovenian SMEs and the second among master program students which enrolled to the Management e-business course. Both respondents

Table 8). Both groups assessed the impacts on a 5degree scale, where 1 means "not agree at all" and 5 "totally agree".

Table 8. E-business impacts expressed their opinion about the implementation of e-business regarding the impacts and obstacles in their companies and their environment.

In Fall 2008, a telephone research was made among a sample of 49 Slovenian SMEs (12). There were 19 micro, 13 small and 17 medium-sized enterprises included in the research.

The second research was made among postgraduate students who finished Management e-business (MeB) course in March 2009. From 37 students enrolled in the course 26 provided answers to our survey $(70.3 \%$ response).

In the first part of the survey the possible ebusiness impacts were researched (

\begin{tabular}{|c|c|c|c|}
\hline Implementing of e-business... & SME & MeB students & Sign. \\
\hline ... make information access more rapid & 4.6 & 4.8 & 0.17 \\
\hline ... enable to acquire new knowledge & 4.4 & 4.7 & 0.09 \\
\hline ... increase enterprise effectiveness & 4.3 & 4.5 & 0.23 \\
\hline ... enable the competitive advantage & 4.2 & 4.5 & 0.26 \\
\hline$\ldots$ because of the enterprise management & 4.2 & 3.6 & 0.01 \\
\hline$\ldots$ increase the products/services sales & 4.1 & 4.2 & 0.53 \\
\hline$\ldots$ increase the profit & 4.1 & 3.9 & 0.56 \\
\hline ... increase communication with customers & 4.1 & 3.8 & 0.31 \\
\hline$\ldots$ increase enterprise reliability & 4.0 & 3.7 & 0.19 \\
\hline ... improve the relationship with customers & 4.0 & 4.1 & 0.70 \\
\hline ... standardize business processes & 4.0 & 4.4 & 0.09 \\
\hline ... integrate business processes & 3.9 & 4.2 & 0.15 \\
\hline ... because of the purchaser demand/pressure & 3.9 & 3.4 & 0.05 \\
\hline ... increase communication with suppliers & 3.8 & 3.9 & 0.67 \\
\hline ... retain the enterprise market position & 3.8 & 3.7 & 0.80 \\
\hline$\ldots$ decrease enterprise costs & 3.7 & 4.3 & 0.01 \\
\hline$\ldots$ increase the product/service quality & 3.7 & 3.8 & 0.88 \\
\hline ... increase communication inside enterprise & 3.6 & 3.9 & 0.17 \\
\hline ... decrease paper consumption & 3.6 & 4.5 & 0.00 \\
\hline ... because of the employee demand/pressure & 3.6 & 3.1 & 0.03 \\
\hline$\ldots$ retain the connection to its competitors & 3.5 & 3.8 & 0.25 \\
\hline$\ldots$ shorter delivery time & 3.1 & 3.8 & 0.01 \\
\hline ... because of the supplier demand/pressure & 3.0 & 3.1 & 0.73 \\
\hline
\end{tabular}

On average MeB students assessed the statements presented

Table $\mathbf{8}$ with 3.9, which is almost on same level as the SMEs did (3.8). Both groups believed that the most positive impact of e-business implementation is more rapid access to information (SME: 4.6, MeB: 4.8) and the possibility to acquire new knowledge (SME: 4.4, MeB: 4.7). The introduction of e-business in enterprises improves the competitive advantages (MeB: 4.5, SME: 4.2) and the enterprise effectiveness (SME: 4.3, MeB: 4.5). The lowest assessments of both groups are 
determined to the reasons why the e-business is implement - according to both groups of Table 8).

In addition to the positive impact of e-business implementation there are still many obstacles which prevent the extent of e-business implementation in surveyed enterprises and which generally reflect student opinions. In the second part of the questionnaire both surveyed groups selected one or more choices presented in Error! Reference source not found.

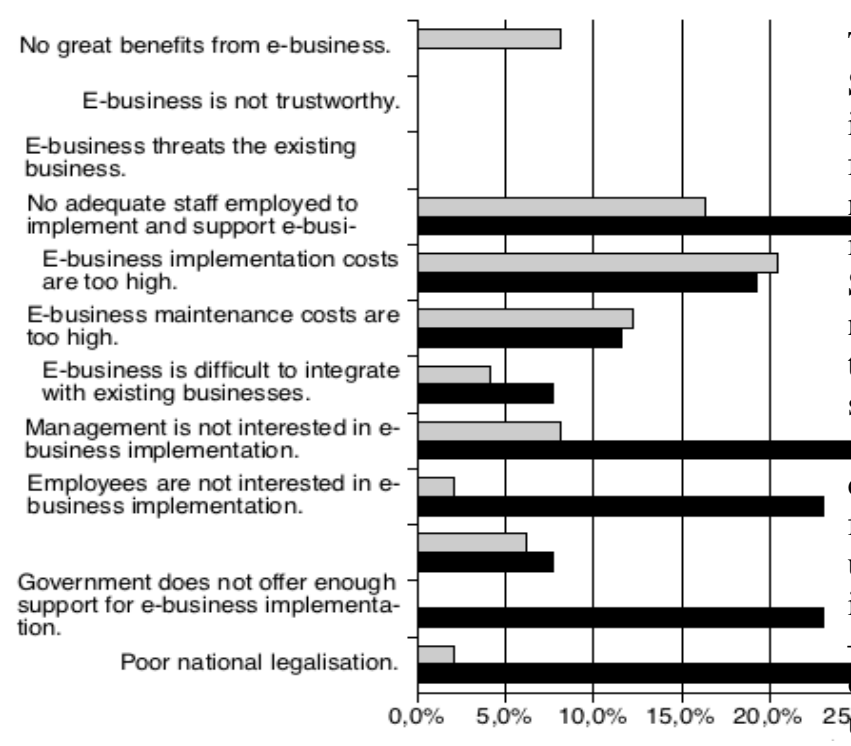

Figure 1. Obstacles for e-business implementation (in \%)

It is interesting that according to students main obstacles for e-business implementation are inadequate staff support $(50.0 \%)$ and from the enterprise perspective the implementation costs $(20.4 \%)$. From the students point of view the costs as an obstacle is placed 6th- with $19.2 \%$. None respondent stressed that e-business is not trustworthy or that e-business treats the existing business. Additionally, students believed that there are great benefits from e-business as well.

In 2008, the National Statistics started to monitored the positive impact in enterprises which implemented ICT during the last two years (Table 9).

Table 9. Awareness of ICT implementing positive impacts (in \%)

\begin{tabular}{|l|c|c|c|}
\hline \multicolumn{1}{|c|}{$\begin{array}{c}\text { There are no } \\
\text { positive impact on }\end{array}$} & Micro & Small & $\begin{array}{c}\text { Medium- } \\
\text { sized }\end{array}$ \\
\hline $\begin{array}{l}\text { _. simplifying } \\
\text { everyday activities }\end{array}$ & 74.4 & 69.4 & 47.4 \\
\hline .. releasing & 75.1 & 70.1 & 51.0 \\
\hline
\end{tabular}

respondents e-business was not implement because

\begin{tabular}{|l|c|c|c|}
\multicolumn{1}{|c}{ of someone's } & \multicolumn{3}{c|}{ demand/pressure } \\
\hline $\begin{array}{l}\text { enterprise resources } \\
\text { revenue }\end{array}$ & 75.9 & 72.2 & 56.4 \\
\hline $\begin{array}{l}\text {.. developing } \\
\text { product/services }\end{array}$ & 76.2 & 73.2 & 58.5 \\
\hline
\end{tabular}

In all categories presented in Table 9 more positive impacts are recognized by medium-sized enterprises than by small or micro enterprises.

\section{CONCLUSION}

The portion of the expenditure for IT purposes in Slovenia is below the EU countries, which results in a lower extent of e-business activities. Due to the fact that poor telecommunication infrastructure is not an issue in Slovenia other factors have an impact on ICI usage for business purposes among $\$ M E s$ such as scarcity of IT res $\phi$ urces. SMEs could not afford to employ their own IT experts therefore the majority of IT activities are oussuY SME In $_{\mathrm{s}}$ a mall country such as Slovenia, finding adequate mpanies, which offer appropriate IT services, could represent a real problem. Another problem, found in our research, is related to the software used for e-business activities. Open source software is not frequently used among Slovenian enterprises - only $7.3 \%$ of surveyed micro enterprises, $11.5 \%$ wrsmarl and $15.5 \%$ of medium-sized enterprises

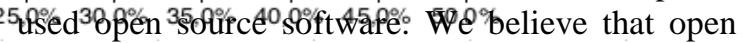
source solutions usage may lower e-business software costs and consequently eliminate main ebusiness obstacles and therefore help SMEs to be more e-business active and consequently enlarge their markets and business.

Regarding e-business impact and obstacles we found that e-business implementation was done mostly due to management demand or pressure and impacts communication inside and outside the enterprise. Both groups of respondents - SMEs and master e-business students believed that greater accessibility of information is one of major positive impacts of e-business and interestingly SMEs do not believe that shorter delivery time is an important impact of e-business.

With regard to the obstacles, SMEs and students had different opinions. SMEs believed that ebusiness implementation or maintenance cost could be a serious obstacle for e-business implementation and usage. On the other hand, students believed that especially lack of staff, uninterested management, employees and government together with poor national legislation are major obstacles for e-business. Both groups agreed that e-business implementation costs are too high. 
The comparison of SMEs ICT usage for e-business purpose shows that there is a gap between ICT usage among Slovenian SMEs and those in the EU and broader. The survey of the impact of e-business usage and obstacles for e-business implementation among SMEs and students show where we should focus the attention and action to improve ICT usage for e-business purposes among Slovenian SMEs.

\section{REFERENCES}

1. Capgemini. (2006). Online Availability of Public Sevices: How Is Europe Progressing? Web Based Survey on Electronic Public Services. Report of the $6^{\text {th }}$ Measurement, June 2006. Available: http://ec.europa.eu/information_society/eeurop e/i2010/docs/benchmarking/online availability 2006.pdf (18. 2. 2008).

2. Chaffey, D. (2007). E-business and ECommerce Management - Strategy, Implementation and Practice, $3^{\text {th }}$ ed. Harlow: Pearson Education.

3. EC - European Commission. Enterprise and Industry - SME Definition. Available: http://ec.europa.eu/enterprise/enterprise policy /sme_definition/index_en.htm (16. 2. 2008).

4. EC - European Commission. Enterprise and Industry - Facts and figures. (2008). Available:

http://ec.europa.eu/enterprise/entrepreneurship/ facts_figures.htm (23.3. 2008).

5. EC - European Commission. (2008). The European e-Business Report 2008 - The impact of ICT and e-business on firms, sectors and the economy. $6^{\text {th }}$ Synthesis Report of the Sectoral e-Business Watch. Available: http://www.ebusiness-

watch.org/key reports/documents/EBR08.pdf (22. 12. 2008).

6. Eurostat. (2007). Science and Technology. Available:

http://epp.eurostat.ec.europa.eu/portal/page?_p ageid $=1090,30070682,1090 \quad 30298591 \&$ dad =portal\& schema=PORTAL (25. 3. 2008).

7. Eurostat. (2004). Community survey on ICT usage and E-commerce in Enterprises. Statistics in Focus 2005/9.

8. IDC. (2004). Analiza slovenskega sektorja IKT kot osnova za strategijo njegovega razvoja. Ljubljana: Gospodarska zbornica Slovenije, Združenje za informatiko in telekomunikacije.

9. Natek, S. and Lesjak, D. (2006). Information process reengineering: where to start business and how to decide?. Issues inf. syst., 2(7), 7782.

10. SIBIS - Statistical Indicators Benchmarking the Information Society. (2008). Available: http://www.sibis-eu.org/reports/country.htm (22. 12. 2008).

11. Stare, M., Kmet, R. and Bučar, M. (2004). Slovenia - on the Way to the Information Society. Ljubljana: Institute of Macroeconomic Analysis and Development.

12. Sulčič, V. (2008). Uporaba informacijskokomunikacijske tehnologije za podporo poslovnih procesov. Koper: UP Fakulteta za management.

13. SURS - Statistični urad RS. (2007). Statistical Yearbook. Available: http://www.stat.si/letopis/index_letopis.asp (16. 2. 2008).

14. SURS - Statistični urad RS. (2007). Uporaba informacijsko-komunikacijske tehnologije $\mathrm{v}$ podjetjih z 10 in več zaposlenimi osebami. 1. Četrtletje 2007. Available: http://www.stat.si/novica_prikazi.aspx?id=128 $\underline{4}$ (17. 2. 2008).

15. SURS - Statistični urad RS. (2009) SI-STAT podatkovni protal. Available: http://www.stat.si/pxweb/Dialog/statfile2.asp (6. 4. 2009)

16. Turban E., D. King. J. McKay, P. Marshall, J. Lee and D. Viehland. (2008). Electronic Commerce - A Managerial Perspective. New Jersey: Pearson Prentice Hall.

17. Turban E., D. King and J. Lang. (2009) Introduction to Electronic Commerce, $2^{\text {nd }} \mathrm{ed}$. New Jersey: Pearson Prentice Hall.

18. Vehovar, V. and Jovan, M. (2003). Companies Slovenia: EU 2002/2003, Comparisons RIS: SIBIS. Available: http://slovenia.ris.org/index.php?fl=2\&lact=1 $\underline{\text { bid }=64 \& \text { parent }=13 \& \text { cat }=120 \& p 1=276 \& p 2=}$ 285\&id=334 (15. 10. 2004).

19. WorldBank - Data\&Statistics: Information and Communication Technologies tables. (2008). Available: http://web.worldbank.org/WBSITE/EXTERN AL/DATASTATISTICS/0,,contentMDK:2048 7483 isCURL:Y menuPK:1192714 pagePK: 64133150 piPK:64133175 theSitePK:239419 ,00.html 